\title{
日本循環器学会指定 循環器専門医研修施設
}

\author{
北海道地区 \\ 《北海道》 \\ 北海道大学病院 \\ 札幌医科大学附属病院 \\ 旭川医科大学病院 \\ 函館中央病院 \\ 医療法人王子総合病院 \\ 社会医療法人延山会 北成病院 \\ 斗南病院 \\ 帯広厚生病院 \\ 市立釧路総合病院 \\ 社会福祉法人函館厚生院 函館五稜郭病院 \\ 札幌循環器病院 \\ NTT 東日本札幌病院 \\ 北海道大野記念病院 \\ カレスサッポロ北光記念病院 \\ 市立旭川病院 \\ 旭川赤十字病院 \\ 手稲渓仁会病院 \\ 函館市医師会病院 \\ 製鉄記念室蘭病院 \\ 札幌南一条病院 \\ 市立函館病院 \\ 国立病院機構 函館病院 \\ 市立札幌病院 \\ 医療法人北晨会恵み野病院 \\ 砂川市立病院 \\ 地域医療機能推進機構 札幌北辰病院 \\ $J R$ 札幌病院 \\ 釧路三慈会病院 \\ カレスサッポロ 時計台記念病院 \\ 社会医療法人母恋 天使病院 \\ 札幌東徳洲会病院 \\ 北海道社会事業協会 帯広病院 \\ 岩見沢市立総合病院 \\ 北見赤十字病院 \\ $\mathrm{JA}$ 北海道厚生連遠軽厚生病院 \\ 江別市立病院 \\ $\mathrm{JA}$ 北海道厚生連 網走厚生病院 \\ 北斗病院 \\ 勤医協中央病院 \\ 苫小牧市立病院 \\ 厚生連総合病院札幌厚生病院 \\ 市立根室病院 \\ 渓和会江別病院 \\ 独立行政法人国立病院機構 帯広病院 \\ 新札幌循環器病院 \\ 社会医療法人禎心会 札幌禎心会病院 \\ 医) 社団 SSJ 札幌整形循環器病院 \\ 小樽市立病院 \\ 札幌心臓血管クリニック \\ 釧路孝仁会記念病院 \\ 札幌中央病院 \\ 札幌白石記念病院 \\ 愛心メモリアル病院 \\ 北海道医療センター \\ 名寄市立総合病院 \\ 北海道社会事業協会小樽病院 \\ 旭川厚生病院 \\ KKR 札幌医療センター \\ 北海道循環器病院
}

北海道中央労災病院

総合病院伊達赤十字病院

$$
\text { 東 北地 区 }
$$

《青森県》

弘前大学医学部附属病院

青森県立中央病院

八戸市立市民病院

むつ総合病院

青森市民病院

八戸赤十字病院

つがる西北五広域連合つがる総合病院 《岩手県》

岩手医大附属病院・循環器医療センター 岩手県立中央病院

岩手県立胆沢病院

岩手県立磐井病院

岩手県立中部病院

岩手県立二戸病院

盛岡赤十字病院

《宮城県》

東北大学病院

東北労災病院

仙台循環器病センター

仙台市医療センター仙台オープン病院

公益財団法人宫城厚生協会坂総合病院

仙台市立病院

仙台徳洲会病院

独立行政法人国立病院機構 仙台医療センター

東北医科薬科大学病院

(一財) 厚生会 仙台厚生病院

気仙沼市立病院

東北公済病院

大崎市民病院

みやぎ県南中核病院

栗原市立栗原中央病院

石巻赤十字病院

《秋田県》

秋田大学医学部附属病院

平鹿総合病院

中通総合病院

秋田県立脳血管研究センター

秋田厚生医療センター

秋田赤十字病院

大曲厚生医療センター

市立秋田総合病院

《山形県》

山形大学医学部附属病院

山形市立病院済生館

山形県立中央病院

米沢市立病院

鶴岡市立荘内病院

山形県立新庄病院

日本海総合病院

北村山公立病院

公立置賜総合病院

庄内余目病院

\section{《福島県》}

福島県立医科大学医学部附属病院

公益財団法人 星総合病院

いわき市立総合般城共立病院

会津中央病院
竹田綜合病院

福島労災病院

(一財) 太田綜合病院附属太田西/内病院 総合南東北病院

社会医療法人福島厚生会 福島第一病院 福島県立医科大学 会津医療センター

公立相馬総合病院

医療生協わたり病院

福島赤十字病院

大原綜合病院

白河厚生総合病院

医療法人平心会須賀川病院

湯浅報恩会寿泉堂綜合病院

\section{関東甲信越地区}

\section{《茨城県》}

筑波大学附属病院

土浦協同病院

東京医科大学茨城医療センター

社会福祉法人水戸済生会総合病院

筑波記念病院

筑波メディカルセンター病院

(株) 日立製作所日立総合病院

国立病院機構 水戸医療センター

総合守谷第一病院

茨城西南医療セン夕一病院

茨城県立中央病院

日立製作所ひたちなか総合病院

小山記念病院

水戸ブレインハートセンター

水戸協同病院

(医)社団常仁会牛久愛和総合病院

《栃木県》

獨協医科大学病院

自治医科大学附属病院

杤木県済生会宇都宮病院

足利赤十字病院

JCHO うつのみや病院

新小山市民病院

佐野厚生総合病院

獨協医科大学日光医療センター

宇都宮記念病院

国際医療福祉大学病院

国立病院機構栃木医療センター

《群馬県》

群馬大学医学部附属病院

高崎総合医療センター

群馬県立心臓血管センター

医療法人北関東循環器病院

群馬県済生会前橋病院

公立藤岡総合病院

前橋赤十字病院

公立富岡総合病院

群馬中央病院

伊勢崎市民病院

邑楽館林医療事務組合館林厚生病院

医療法人鶴谷会鶴谷病院

高瀬クリニック

医療法人社団日高会 日高病院

SUBARU 健康保険組合太田記念病院 東邦病院 
《埼玉県》

獨協医科大学埼玉医療センター 埼玉医科大学総合医療センター 防衛医科大学校病院

さいたま赤十字病院

埼玉石心会病院

自治医科大学附属さいたま医療センター

埼玉医科大学国際医療センター

さいたま市立病院

医療法人社団東光会戸田中央総合病院

小川赤十字病院

国立病院機構 埼玉病院

深谷赤十字病院

川口市立医療センター

埼玉県済生会栗橋病院

埼玉県立循環器・呼吸器病センター

済生会川口総合病院

川口工業総合病院

越谷市立病院

医療法人社団愛友会上尾中央総合病院 草加市立病院

春日部中央総合病院

彩の国 東大宮メディカルセンター

医療法人社団松弘会 三愛病院

国立病院機構 西埼玉中央病院

埼玉東部循環器病院

秀和総合病院

新座志木中央総合病院

北里大学メディカルセンター

埼玉メディカルセンター

健仁会 益子病院

みさと健和病院

行田総合病院

イムス富士見総合病院

さいたま市民医療センター

新久喜総合病院

社会医療法人社団尚篤会赤心堂病院

かわぐち心臟呼吸器病院

イムス三芳総合病院

春日部市立医療センター

《千葉県》

千葉大学医学部附属病院

帝京大学ちば総合医療センター

船橋市立医療センター

千葉県勤労者医療協会船橋二和病院

医療法人社団保健会谷津保健病院

地域医療機能推進機構 千葉病院

千葉市立海浜病院

東京慈恵会医科大学附属柏病院

地方独立行政法人 総合病院国保旭中央病院

労働者健康福祉機構千葉労災病院

千葉県循環器病センター

亀田総合病院

千葉西総合病院

松戸市立総合医療センター

新東京病院

順天堂大学医学部附属浦安病院

東邦大学医療センター佐倉病院

日本医科大学千葉北総病院

医療法人沖縄徳洲会千葉徳洲会病院

(医財) 東京勤労者医療会東葛病院

千葉市立青葉病院

君津中央病院

東京歯科大学市川総合病院

医療法人財団明理会 新松戸中央総合病院

創進会みつわ台総合病院

東京ベイ・浦安市川医療センター

千葉県済生会習志野病院

医療法人社団誠馨会千葉中央メディカルセンター
成田赤十字病院

小張総合病院・小張総合クリニック

東京女子医科大学八千代医療セン夕ー

島田総合病院

鎌ケ谷総合病院

おおたかの森病院

千葉メディカルセンター

千葉県救急医療センター

国立病院機構 千葉医療センター

柏市立柏病院

《東京都》

東京大学医学部附属病院

東京医科歯科大学医学部附属病院

東京慈恵会医科大学附属病院

東京慈恵会医科大学葛飾医療センター

日本医科大学付属病院

日本医科大学多摩永山病院

順天堂大学医学部附属順天堂医院

慶應義塾大学病院

東京女子医科大学病院

東京女子医科大学東医療センター

東京医科大学病院

東京医科大学八王子医療センター

昭和大学病院

東邦大学医療センター大橋病院

東邦大学医療センター大森病院

日本大学医学部附属板橋病院

日本大学病院

帝京大学医学部附属病院

杏林大学医学部付属病院

三井記念病院

東京警察病院

東京莪信病院

国家公務員共済組合連合会虎の門病院

心臟血管研究所付属病院

東京高輪病院

東京都済生会中央病院

NTT 東日本関東病院

東京都立広尾病院

榊原記念病院

独立行政法人国立病院機構 東京医療センター

東京共済病院

公立学校共済組合関東中央病院

国立国際医療研究センター病院

JCHO 東京新宿メディカルセンター

東京都健康長寿医療セン夕ー

武蔵野赤十字病院

立川相互病院

聖路加国際病院

JR 東京総合病院

公立昭和病院

東京慈恵会医科大学附属第三病院

東京労災病院

玉川病院

豊島病院

総合病院厚生中央病院

自衛隊中央病院

北里研究所病院

日本赤十字社東京都支部大森赤十字病院

葛西昌医会病院

東京山手メディカルセンター

東部地域病院

(財) 東京都保健医療公社荏原病院

日本赤十字社医療センター

東京都立多摩総合医療センター

多摩北部医療センター

多摩南部地域病院

同愛記念病院

医療法人社団東光会西東京中央総合病院
社会福祉法人仁生社江戸川病院

東京品川病院

国家公務員共済組合連合会三宿病院

河北総合病院

綾瀬循環器病院

町田市民病院

国立病院機構 東京病院

社会医療法人社団順江会 江東病院

東京都立大塚病院

日野市立病院

東海大学医学部付属八王子病院

公立福生病院

(医)社団松和会 池上総合病院ハートセン夕ー

東京都立墨東病院

東京臨海病院

医療法人社団苑田会 苑田第一病院

永寿総合病院

大崎病院東京ハートセンター

順天堂大学医学部附属練馬病院

東京北医療センター

東京西徳洲会病院

国際医療福祉大学三田病院

博鳳会敬愛病院

順天堂東京江東高齢者医療センター

イムス葛飾ハートセンター

浮間中央病院

府中恵仁会病院

新山手病院

明理会中央総合病院

西新井ハートセンター病院

医療法人財団健貢会 総合東京病院

練馬光が丘病院

東京蒲田病院

昭和大学江東豊洲病院

石川島記念病院

練馬総合病院

森山記念病院

ニューハート・ワタナベ国際病院

永生会 南多摩病院

国家公務員共済組合連合会立川病院

立正佼成会附属佼成病院

医療法人社団明芳会板橋中央総合病院

公立阿伎留医療センター

大久保病院

医療法人財団荻窪病院

青梅市立総合病院

社会医療法人財団大和会東大和病院

国立病院機構 災害医療センター

博慈会記念総合病院

《神奈川県》

聖マリアンナ医科大学病院

聖マリアンナ医科大学横浜市西部病院

横浜市立大学附属病院

昭和大学藤が丘病院

北里大学病院

東海大学医学部付属病院

関東労災病院

横浜栄共済病院

藤沢市民病院

神奈川県立循環器呼吸器病センター

国立病院機構 横浜医療センター

湘南鎌倉総合病院

横須賀市立市民病院

けいゆう病院

独立行政法人労働者健康安全機構横浜労災病院

横浜市立みなと赤十字病院

横浜南共済病院

横須賀共済病院

国際親善総合病院 
茅ヶ崎市立病院

社会医療法人財団石心会 川崎幸病院

相模原協同病院

済生会横浜市南部病院

聖隷福祉事業団聖隷横浜病院

横浜市立市民病院

平塚市民病院

日本鋼管病院

川崎市立川崎病院

横浜市立大学附属市民総合医療センター

AOI 国際病院

日本医科大学武蔵小杉病院

厚木市立病院

小田原市立病院

帝京大学医学部附属溝口病院

医療法人邦友会小田原循環器病院

長津田厚生総合病院

湘南藤沢徳洲会病院

$\mathrm{JCHO}$ 横浜中央病院

横浜旭中央総合病院

藤沢湘南台病院

聖マリアンナ医科大学東横病院

昭和大学横浜市北部病院循環器センター

総合高津中央病院

横浜総合病院ハートセンター

湘南東部総合病院

横浜保土ヶ谷中央病院

大和市立病院

東海大学医学部付属大磯病院

川崎市立多摩病院

済生会横浜市東部病院

海老名総合病院

秦野赤十字病院

大和成和病院

総合新川橋病院

相模野病院

新百合ヶ丘総合病院

戸塚共立第二病院

川崎市立井田病院

東芝林間病院

横須賀市立うわまち病院

医療法人五星会菊名記念病院

東名厚木病院

国立病院機構 相模原病院

平塚共済病院

《新潟県》

新潟大学医歯学総合病院

長岡赤十字病院

新潟医療センター

新潟市民病院

立川綜合病院

済生会新潟第二病院

新潟県立新発田病院

新潟県立中央病院

信楽園病院

木戸病院

新潟県厚生連長岡中央綜合病院

上越総合病院

《山梨県》

山梨大学医学部附属病院

山梨県立中央病院

(社) 山梨勤労者医療協会甲府共立病院 甲府城南病院

山梨赤十字病院

公益財団法人山梨厚生会山梨厚生病院 《長野県》

信州大学医学部附属病院

長野赤十字病院

長野県厚生連北信総合病院
昭和伊南総合病院

松本協立病院

安曇野赤十字病院

長野松代総合病院

信州上田医療センター

慈泉会相澤病院

飯田市立病院

諏訪中央病院

岡谷市民病院

長野県立こども病院

健和会病院

北アルプス医療センターあづみ病院

栗山会 飯田病院

長野医療生活協同組合長野中央病院

JA 長野厚生連佐久総合病院佐久医療セン夕一 長野県厚生連篠ノ井総合病院

諏訪赤十字病院

長野市民病院

東 海 地 区

《岐阜県》

岐阜大学医学部附属病院

岐阜県総合医療センター

岐阜市民病院

羽島市民病院

大垣市民病院

松波総合病院

岐阜赤十字病院

岐阜県立多治見病院

岐阜県厚生連 揖斐厚生病院

岐阜県厚生連 岐北厚生病院

木沢記念病院

朝日大学病院

公立学校共済組合 東海中央病院

JA 岐阜厚生連 東濃厚生病院

JA 岐阜厚生連 久美愛厚生病院

岐阜ハートセンター

JA 岐阜厚生連中濃厚生病院

総合病院中津川市民病院

可児とうのう病院

\section{《静岡県》}

浜松医科大学医学部附属病院

総合病院 聖隷浜松病院

国立病院機構 静岡医療センター 静岡県立総合病院

静岡済生会総合病院

静岡市立静岡病院

市立島田市民病院

聖隷三方原病院

中東遠総合医療センター

磐田市立総合病院

藤枝市立総合病院

浜松労災病院

浜松医療センター

順天堂大学医学部附属静岡病院

焼津市立総合病院

岡村記念病院

富士宮市立病院

富士市立中央病院

菊川市立総合病院

社団法人有隣厚生会富士病院

静岡県立静岡がんセンター

静岡徳洲会病院

市立湖西病院

静岡赤十字病院

$\mathrm{JA}$ 静岡厚生連 遠州病院

沼津市立病院

浜松赤十字病院
《愛知県》

名古屋大学医学部附属病院

名古屋市立大学病院

藤田保健衛生大学病院

愛知医科大学病院

豊橋市民病院

安城更生病院

刈谷豊田総合病院

名古屋鉄道健康保険組合名鉄病院

独立行政法人地域医療機能推進機構中京病院

国立病院機構 名古屋医療センター

名城病院

名古屋第二赤十字病院

愛知県厚生連豊田厚生病院

小牧市民病院

名古屋第一赤十字病院

名古屋掖済会病院

中部ろうさい病院

協立総合病院

春日井市民病院

愛知厚生連 渥美病院

西尾市民病院

卜ヨ夕記念病院

半田市立半田病院

一宫市立市民病院

社会医療法人宏潤会 大同病院

総合病院南生協病院

愛知県厚生連 江南厚生病院

公立陶生病院

愛知厚生連 海南病院

蒲郡市民病院

岡崎市民病院

旭労災病院

名古屋市立東部医療センター

津島市民病院

名古屋記念病院

名古屋徳洲会総合病院

豊橋ハートセンター

藤田保健衛生大学坂文種報徳會病院

医療法人偕行会 名古屋共立病院

愛知県厚生農業協同組合連合会 稲沢厚生病院

総合犬山中央病院

名古屋ハートセンター

一宮西病院

稻沢市民病院

公立西知多総合病院

総合大雄会病院

豊川市民病院

碧南市民病院

《三重県》

三重大学医学部附属病院

三重県立総合医療センター

地方独立行政法人 桑名市総合医療セン夕ー 三重県厚生連鈴鹿中央総合病院

永井病院

三重県厚生連松阪中央総合病院

済生会松阪総合病院

医療法人同心会遠山病院

伊勢赤十字病院

市立四日市病院

松阪市民病院

国立病院機構 三重中央医療センター

名張市立病院

岡波総合病院

四日市羽津医療センター

三重ハートセンター 


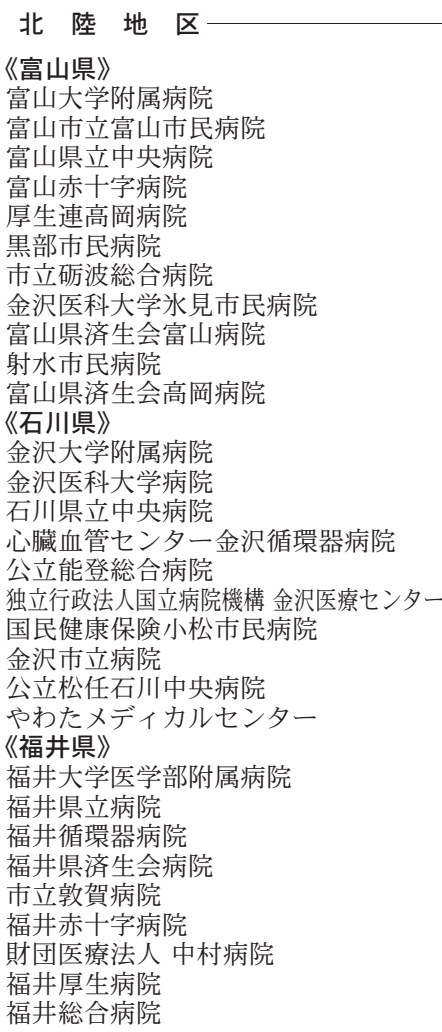

\section{近 畿 地区}

《滋賀県》

滋賀医科大学医学部附属病院

大津赤十字病院

彦根市立病院

滋賀県立総合病院

長浜赤十字病院

市立大津市民病院

済生会滋賀県病院

近江八幡市立総合医療センター 市立長浜病院

地域医療機能推進機構 滋賀病院

医療法人社団昂会湖東記念病院

高島市民病院

草津総合病院

公立甲賀病院

医療法人弘英会琵琶湖大橋病院

《京都府》

京都大学医学部附属病院

京都府立医科大学附属病院

京都第二赤十字病院

西陣病院

京都第一赤十字病院

三菱京都病院

京都鞍馬口医療センター

京都医療センター

医療法人財団康生会武田病院

医療法人医仁会武田総合病院

洛和会音羽病院

京都桂病院

舞鶴共済病院

京都市立病院

京都岡本記念病院
綾部市立病院

京都中部総合医療センター

医療法人啓信会京都きづ川病院

洛和会丸太町病院

京都府立医科大学附属北部医療センター

京都山城総合医療センター

医療法人社団蘇生会蘇生会総合病院

京丹後市立久美浜病院

市立福知山市民病院

田辺中央病院

宇治徳洲会病院

医療法人亀岡病院

京丹後市立弥栄病院

公益社団法人 京都保健会京都民医連中央病院 《大阪府》

大阪大学医学部附属病院

大阪市立大学医学部附属病院

大阪医科大学附属病院

関西医科大学総合医療センター

近畿大学医学部附属病院

国立循環器病研究センター

大阪府済生会中津病院

北野病院

住友病院

桜橋渡辺病院

大阪鉄道病院

大阪急性期・総合医療センター

大阪府三島救命救急センター

松下記念病院

分尾市立病院

医療法人宝生会 PL 病院

大阪南医療センター

社会医療法人同仁会 耳原総合病院

大阪労災病院

大阪回生病院

淀川キリスト教病院

独立行政法人国立病院機構 大阪医療センター

大阪赤十字病院

大阪警察病院

公益財団法人日本生命済生会日本生命病院

関西電力病院

地域医療機能推進機構 大阪病院

大阪暁明館病院

社会医療法人愛仁会千船病院

医療法人河内友紘会河内総合病院

堺市立総合医療センター

清恵会病院

社会医療法人ペガサス馬場記念病院

医療法人生長会ベルランド総合病院

国家公務員共済組合連合会 大手前病院

大阪みなと中央病院

南大阪病院

社会医療法人仙養会北摄総合病院

高槻赤十字病院

若草第一病院

和泉市立総合医療センター

医療法人愛仁会高槻病院

星ヶ丘医療センター

市立ひらかた病院

地方独立行政法人市立東大阪医療センター

医真会八尾総合病院

市立柏原病院

市立岸和田市民病院

大阪市立総合医療センター

野江病院

多根総合病院

大阪府済生会千里病院

市立豊中病院

医療法人生長会府中病院
りんくう総合医療センター

医療法人育和会 育和会記念病院

大阪府済生会泉尾病院

医療法人医誠会医誠会病院

NTT 西日本大阪病院

枚方公済病院

医療法人 春秋会城山病院

石切生喜病院

済生会吹田病院

医療法人貴医会貴島中央病院

富永病院

祐生会みどりヶ丘病院

済生会富田林病院

医療法人橘会 東住吉森本病院

医療法人徳洲会岸和田徳洲会病院

箕面市立病院

市立吹田市民病院

大阪府済生会茨木病院

守口生野記念病院

守口敬仁会病院

高石藤井心臟血管病院

摄南総合病院

加納総合病院

八尾徳洲会総合病院

医療法人錦秀会阪和記念病院

医療法人朋愛会 朋愛病院

社会医療法人大道会 森之宮病院

吹田徳洲会病院

医療法人マックシール巽病院

市立池田病院

浅香山病院

関西医科大学附属病院

《兵庫県》

神戸大学医学部附属病院

兵庫医科大学病院

神戸掖済会病院

済生会兵庫県病院

独立行政法人労働者健康安全機構神戸労災病院 神戸中央病院

国立病院機構 神戸医療センター

兵庫県立淡路医療センター

兵庫県立尼崎総合医療センター

公立学校共済組合 近畿中央病院

宝塚市立病院

兵庫県立姫路循環器病センター

独立行政法人国立病院機構 姫路医療セン夕ー 社会医療法人愛仁会明石医療センター

北播磨総合医療センター

市立加西病院

神鋼記念病院

三菱神戸病院

関西労災病院

三田市民病院

兵庫県立柏原病院

社会医療法人製鉄記念広畑病院

加古川中央市民病院

赤穂市民病院

神戸市立医療センター中央市民病院

医療法人明和病院

市立伊丹病院

六甲アイランド甲南病院

公立豊岡病院組合立豊岡病院

神戸市立西神戸医療センター

医療法人川崎病院

公立八鹿病院

医療法人協和会協立病院

明石市立市民病院

東宝塚さとう病院

市立川西病院 
神戸赤十字病院

ツカザキ病院

尼崎中央病院

西宮渡辺心臟脳・血管センター

はくほう会セントラル病院

晋真会ベリタス病院

医療法人社団さくら会 高橋病院

兵庫県立こども病院

みどり病院

西宮市立中央病院

神戸徳洲会病院

姫路赤十字病院

兵庫県立西宫病院

兵庫県立加古川医療センター 《奈良県》

奈良県立医科大学附属病院

市立奈良病院

奈良県総合医療センター

奈良県西和医療センター

天理よろづ相談所病院

医療法人康仁会西の京病院

社会医療法人高清会 高井病院

近畿大学医学部奈良病院

医療法人新生会 高の原中央病院

医療法人橿原友紘会 大和橿原病院

《和歌山県》

和歌山県立医科大学附属病院

日本赤十字社和歌山医療センター 紀南病院

誠佑記念病院

公立那賀病院

新宫市立医療センター

和歌山労災病院

国保日高総合病院

済生会和歌山病院

橋本市民病院

中 国 地区

\section{《鳥取県》}

鳥取大学医学部附属病院

鳥取県立厚生病院

山陰労桨病院

鳥取県立中央病院

《島根県》

島根大学医学部附属病院

島根県立中央病院

松江赤十字病院

松江市立病院

総合病院松江生協病院

島根県済生会江津総合病院

《岡山県》

岡山大学病院

川崎医科大学附属病院

心臓病センター榊原病院

岡山赤十字病院

独立行政法人国立病院機構 岡山医療セン夕ー 倉敷中央病院

津山中央病院

総合病院岡山協立病院

川崎医科大学総合医療センター

岡山労災病院

岡山済生会総合病院

岡山市立市民病院

《広島県》

広島大学病院

国立病院機構 福山医療センター

福山市民病院

国家公務員共済組合連呉共済病院

県立広島病院
吳医療センター・中国がんセンター

中国労災病院

JA 広島総合病院

土谷総合病院

広島市立安佐市民病院

福山循環器病院

広島赤十字・原爆病院

済生会広島病院

広島県厚生農業協同組合連合会尾道総合病院

JR 広島病院

中国電力株式会社中電病院

広島市立広島市民病院

社会医療法人里仁会 與生総合病院

国立病院機構 広島西医療センター

市立三次中央病院

国立病院機構 東広島医療センター マツダ株式会社マツダ病院

《山口県》

山口大学医学部附属病院

山口県立総合医療センター

下関市立市民病院

山口県済生会下関総合病院

国立病院機構 岩国医療センター

関門医療センター

済生会山口総合病院

宇部興産中央病院

地域医療機能推進機構 徳山中央病院

神徳会三田尻病院

医療法人社団成蹊会岡田病院

下関医療センター

周東総合病院

萩市民病院

山口労災病院

綜合病院山口赤十字病院

\section{四国地区}

\section{《徳島県》}

徳島大学病院

国立病院機構 東徳島医療センター

徳島赤十字病院

徳島県立中央病院

吉野川医療センター

川島会川島病院

徳島市民病院

《香川県》

香川大学医学部附属病院

高松赤十字病院

三豊総合病院

香川県立中央病院

香川県立白鳥病院

香川労災病院

総合病院坂出市立病院

医療法人財団博仁会キナシ大林病院

国家公務員共済組合連合会 KKR 高松病院 回生病院

香川県済生会病院

屋島総合病院

\section{《愛媛県》}

愛媛大学医学部附属病院

愛媛県立中央病院

松山赤十字病院

独立行政法人国立病院機構 愛媛医療セン夕ー

愛媛県立新居浜病院

愛媛県立今治病院

喜多医師会病院

市立宇和島病院

市立八幡浜総合病院

西条中央病院

済生会今治病院
済生会西条病院

済生会松山病院

愛媛労災病院

住友別子病院

松山市民病院

《高知県》

高知大学医学部附属病院

高知医療センター

近森病院

高知県立幡多けんみん病院

高知赤十字病院

\section{九 州地 区}

《福岡県》

九州大学病院

福岡大学病院

産業医科大学病院

久留米大学病院

地域医療機能推進機構 九州病院

福岡市立こども病院

国家公務員共済組合連合会浜の町病院

国家公務員共済組合連合会千早病院

福岡大学西新病院

飯塚病院

社会医療法人天神会新古賀病院

小倉記念病院

福岡県済生会福岡総合病院

雪の聖母会聖マリア病院

医療法人社団誠心会萩原中央病院

原三信病院

九州医療センター

北九州市立医療センター

医療法人弘恵会ヨコクラ病院

製鉄記念八幡病院

社会医療法人財団白十字会白十字病院

久留米大学医学部附属医療セン夕ー

医療法人親仁会米の山病院

九州労災病院 門司メディカルセンター

国立病院機構 福岡東医療センター

千鳥橋病院

福岡赤十字病院

福岡青洲会病院

新行橋病院

宗像水光会総合病院

福岡県済生会二日市病院

福岡記念病院

公立学校共済組合九州中央病院

北九州総合病院

福岡和白病院

公立八女総合病院

柳川病院

済生会八幡総合病院

田主丸中央病院

筑後市立病院

福岡山王病院

医療法人社団高邦会 高木病院

九州労災病院

福岡莪信病院

北九州市立八幡病院

医療法人徳洲会福岡徳洲会病院

杉循環器科内科病院

医療法人井上会篠栗病院

\section{《佐賀県》}

佐賀大学医学部附属病院

佐賀県医療センター好生館

唐津赤十字病院

国立病院機構 嬉野医療センター

《長崎県》

長崎大学病院 
医療法人光晴会病院

長崎みなとメディカルセンター

日本赤十字社長崎原爆病院

医療法人宏善会諌早記念病院

独立行政法人国立病院機構 長崎医療セン夕ー

佐世保市総合医療センター

虹が丘病院

大村市民病院心臟血管病センター

長崎記念病院

諫早総合病院

済生会長崎病院

社会医療法人財団 白十字会佐世保中央病院 《熊本県》

熊本大学医学部附属病院

済生会熊本病院

熊本中央病院

熊本赤十字病院

公立玉名中央病院

国立病院機構熊本医療センター

人吉医療センター

医療法人社団寿量会熊本機能病院

国保水俣市立総合医療センター

医療法人杉村会 杉村病院

地域医療機能推進機構熊本総合病院

天草地域医療センター

熊本労災病院
《大分県》

大分大学医学部附属病院

新別府病院

九州大学病院別府病院

国立病院機構 別府医療センター

医療法人輝心会 大分循環器病院

大分医療センター

大分県厚生連鶴見病院

社会医療法人敬和会 大分岡病院

大分市医師会立アルメイダ病院

大分中村病院

大分県立病院

大分県済生会日田病院

《宮崎県》

宮崎大学医学部附属病院

宮崎市郡医師会病院

藤元総合病院

宫崎江南病院

都城市郡医師会病院

古賀総合病院

宮崎県立延岡病院

県立宫崎病院

《鹿児島県》

鹿児島大学病院

国立病院機構 鹿児島医療センター

社会医療法人天陽会中央病院
総合病院鹿児島生協病院

鹿児島市医師会病院

鹿児島市立病院

大隅鹿屋病院

国立病院機構 指宿医療センター

鹿児島県立薩南病院

《沖縄県》

琉球大学医学部附属病院

沖縄協同病院

沖縄県立南部医療センター・こども医療センター 那覇市立病院

沖縄県立中部病院

浦添総合病院

社会医療法人敬愛会 中頭病院

中部徳洲会病院

北部地区医師会附属病院

沖縄赤十字病院

医療法人陽心会大道中央病院

沖縄県立宫古病院

豊見城中央病院

大浜第一病院

医療法人博愛会牧港中央病院

ハートライフ病院

研修施設 計 1,019 施設

なお，研修施設一覧は 2018 年 7 月 1 日現在の情報を元に作成しております.

今後名称等に変更が生ずる場合がございますのでご了承願います。また，今後新たに指定・辞退・停止される施設もあり ますので, 詳細や不明な点につきましては(一社) 日本循環器学会事務局へお問い合わせ下さい。

《専門医担当：TEL(03)5501-0864 FAX (03) 5501-9855/e-mail: senmoni@j-circ.or.jp》 


\section{日本循環器学会指定 循環器専門医研修関連施設}

北海 道地区

《北海道》

市立室蘭総合病院

札幌共立五輪橋病院

滝川市立病院

市立芦別病院

市立千歳市民病院

北海道社会事業協会 富良野病院

旭川リハビリテーション病院

八雲総合病院

社会医療法人延山会 西成病院

森山病院

千寿会 三愛病院

女満別中央病院

華岡青洲記念心臓血管クリニック

社会医療法人母恋 日鋼記念病院

木原循環器科内科医院

北海道立北見病院

留萌市立病院

東 北地区

《青森県》

三沢市立三沢病院

(財)黎明楖弘前腷卒中・リハビリテーションセンター

あおもり協立病院

十和田市立中央病院

《岩手県》

北上済生会病院

岩手県立大船渡病院

岩手県立釜石病院

盛岡友愛病院

《宮城県》

$\mathrm{JCHO}$ 仙台病院

石巻市立病院

総合南東北病院

仙台赤十字病院

《秋田県》

能代厚生医療センター

由利組合総合病院

大館市立総合病院

市立横手病院

本荘第一病院

《山形県》

小白川至誠堂病院

公立学校共済組合東北中央病院

済生会山形済生病院

山形県立河北病院

鶴岡協立病院

財団法人三友堂病院

《福島県》

済生会福島総合病院

医療法人辰星会枅記念病院

南相馬市立総合病院

敬愛会 福島南循環器科病院

関東甲信越地区

《茨城県》

JA とりで総合医療センター

北茨城市民病院

誠潤会水戸病院

社会医療法人 愛宣会 ひたち医療センター 古河赤十字病院

つくばセントラル病院

鹿嶋ハートクリニック

医療法人徳洲会 古河総合病院

財団法人筑波学園病院

国立病院機構 霞ケ浦医療セン夕一
神栖済生会病院

《栃木県》

医療法人社団全仁会宇都宫中央病院

とちぎメディカルセンターしもつが

菅間記念病院

芳賀赤十字病院

国際医療福祉大学塩谷病院

《群馬県》

沼田脳神経外科循環器科病院

利根中央病院

イムス太田中央総合病院

《埼玉県》

埼玉医療生活協同組合 羽生総合病院 関越病院

所沢ハートセンター

岩槻南病院

本庄総合病院

埼玉医科大学病院

東埼玉総合病院

堀中病院

埼玉協同病院

(公社) 東松山医師会 東松山医師会病院 《千葉県》

安房地域医療センター

名戸ヶ谷病院

セコメディック病院

柏厚生総合病院

塩田記念病院

東千葉メディカルセンター

国立国際医療研究センター国府台病院

行徳総合病院

成田富里徳洲会病院

《東京都》

東京都教職員互助会三楽病院

医療法人社団大坪会 東和病院

稲城市立病院

東海大学医学部付属東京病院

社会福祉法人康和会久我山病院

大田病院

東京北部病院

社会医療法人社団正志会 南町田病院

社会福祉法人仁生社 江戸川メディケア病院

みなみ野循環器病院

至誠会第二病院

《神奈川県》

医療法人横浜博萌会西横浜国際総合病院

(医)社団一成会たちばな台病院

川崎医療生活協同組合川崎協同病院

昭和大学藤が丘リハビリテーション病院

神奈川県立汐見台病院

葉山ハートセンター

東戸塚記念病院

伊勢原協同病院

神奈川県立足柄上病院

相模原中央病院

横浜新都市脳神経外科病院

済生会神奈川県病院

横浜新緑総合病院

磯子中央病院

《新潟県》

新潟県立燕労災病院

糸魚川総合病院

新潟勤労者医療協会下越病院

柏崎総合医療セン夕一

新潟県厚生連佐渡総合病院

《山梨県》

山梨病院

市立甲府病院
国民健康保険富士吉田市立病院

《長野県》

JA 長野厚生連 浅間南麓こもろ医療センター 社会医療法人抱生会丸の内病院

佐久市立国保浅間総合病院

伊那中央病院

まつもと医療センター

東 海 地 区

《岐阜県》

岐阜県立下呂温泉病院

医療法人社団誠広会平野総合病院

医療法人社団慈朋会澤田病院

多治見市民病院

郡上市民病院

岩砂病院・岩砂マタニティ

《静岡県》

財団法人恵愛会聖隷富士病院

国際医療福祉大学 熱海病院

静岡県立こども病院

ハートセンタ一磐田

のぞみ記念下田循環器・腎臟クリニック

榛原総合病院

JA 静岡厚生連 静岡厚生病院

《愛知県》

名古屋市立緑市民病院

国立長寿医療研究センタ

常滑市民病院

中日病院

名古屋セントラル病院

医療法人宝美会 総合青山病院

寿光会中央病院

八千代病院

知多厚生病院

名古屋市立西部医療センター

成田記念病院

泰玄会病院

名古屋西病院

みよし市民病院

《三重県》

市立伊勢総合病院

尾就総合病院

大台厚生病院

菰野厚生病院

JA 三重厚生連 三重北医療センターいなべ総合病院 三重県立志摩病院

北陸 地 区一

《富山県》

高岡市民病院

富山労災病院

《石川県》

石川県済生会金沢病院

芳珠記念病院

公立羽咋病院

金沢赤十字病院

加賀市医療センター

恵寿総合病院

《福井県》

医療法人初生会福井中央クリニック

公立小浜病院

近 畿 地 区

《滋賀県》

豊郷病院

《京都府》

済生会京都府病院

明治国際医療大学附属病院 
医療法人清仁会シミズ病院

独立行政法人国立病院機構 舞鶴医療セン夕ー 医療法人親友会島原病院

(社) 愛生会 山科病院

洛西ニュータウン病院

医聖会 学研都市病院

医療法人同仁会 京都九条病院

医療法人健康会 新京都南病院

《大阪府》

大阪国際がんセンター

大阪はびきの医療センター

市立貝塚病院

松原徳洲会病院

健康保険組合連合会大阪中央病院

医療法人協仁会 小松病院

市立藤井寺市民病院

第一東和会病院

医療法人警和会北大阪警察病院

医療法人生登会 寺元記念病院

医療法人毅峰会 吉田病院

なにわ生野病院

西淀病院

山弘会上山病院

友紘会総合病院

茨木医誠会病院

《兵庫県》

神戸百年記念病院

一般財団法人甲南会 甲南病院

公立豊岡病院 日高医療セン夕ー

医療法人浩生会舞子台病院

宝塚病院

医療法人赤穂中央病院

西脇市立西脇病院

尼崎新都心病院

兵庫県災害医療センター

真星病院

神戸市立医療センター西市民病院

市立芦屋病院

《奈良県》

宇陀市立病院

大和高田市立病院

恩賜財団済生会御所病院

土庫病院

《和歌山県》

有田市立病院

南和歌山医療センター

中国地区

《鳥取県》

鳥取市立病院

鳥取赤十字病院

《島根県》

浜田医療センター

益田赤十字病院

《岡山県》

重井医学研究所附属病院

倉敷紀念病院

岡山ハートクリニック

しげい病院

《広島県》

医療法人清幸会 三原城町病院

総合病院庄原赤十字病院

医療法人社団啓卯会村上記念病院

尾道市立市民病院
因島医師会病院

高陽二ュータウン病院

広島ハートセンター広島心臓血管クリニック

脳神経センター大田記念病院

《山口県》

光市立大和総合病院

美祢市立病院

周南市立新南陽市民病院

山陽小野田市民病院

医療法人 協愛会 阿知須共立病院

四 国 地 区-

《徳島県》

阿南中央病院

徳島県鳴門病院

徳島県立三好病院

阿南共栄病院

医療法人雙立会碩心館病院

《香川県》

四国こどもとおとなの医療センター 高松平和病院

さぬき市民病院

《愛媛県》

地域医療機能推進機構 宇和島病院

瀬戸内海病院

今治第一病院

よつば循環器科クリニック

和昌会 貞本病院

HITO 病院

星の岡心臟・血管クリニック

愛媛県立南宇和病院

医療法人滴水会吉野病院

《高知県》

地域医療機能推進機構 高知西病院

土佐市立土佐市民病院

高知県立あき総合病院

国立病院機構 高知病院

須崎くろしお病院

高知総合リハビリテーション病院

九 州 地 区

《福岡県》

福岡大学筑紫病院

飯塚市立病院

地域医療機能推進機構 久留米総合病院

健和会大手町病院

社会保険直方病院

中村循環器科心臟外科医院

医療法人福西会 福西会病院

福岡市民病院

医療法人社団シマダ 嶋田病院

$<ら て$ 病院

福岡新水巻病院

草場内科循環器科医院

村上華林堂病院

朝倉医師会病院

国立病院機構 大牟田病院

佐田病院

医療法人夕なみ粕屋南病院

新小文字病院

日本海員掖済会 門司掖済会病院

医療法人医和基会戸畑総合病院

宗像医師会病院

大牟田市立病院
医療法人原信会原口病院循環器科内科

《佐賀県》

医療法人春陽会 上村病院

国立病院機構 佐賀病院

医療法人謙仁会 山元記念病院

済生会唐津病院

新武雄病院

佐賀中部病院

東佐賀病院

《長崎県》

労働者健康安全機構 長崎労災病院

特別医療法人春回会井上病院

長崎県 島原病院

長崎川棚医療センター

北松中央病院

佐世保共済病院

五島中央病院

長崎掖済会病院

《熊本県》

熊本市医師会熊本地域医療センター 済生会みす久病院

熊本再春荘病院

くまもと成城病院

阿蘇医療センター

荒尾市民病院

《大分県》

大分赤十字病院

(社) 津久見市医師会立 津久見中央病院

宇佐高田医師会病院

臼杵市医師会立 コスモス病院

新生会 福島病院

国立病院機構 西別府病院

天心堂へつぎ病院

慈恵会西田病院

仁泉会畑病院

《宮崎県》

藤元中央病院

《鹿児島県》

南風病院

垂水市立医療センター垂水中央病院

出水郡医師会広域医療センター

国分生協病院

鹿児島県立大島病院

鹿児島県立北薩病院

鹿児島厚生連病院

霧島市立医師会医療センター

医療法人鹿屋ハートセンター

川内市医師会立市民病院

出水総合医療セン夕ー

済生会川内病院

医療法人青仁会 池田病院

医療法人浩然会指宿浩然会病院

今給黎総合病院

今村総合病院

徳之島徳洲会病院

県民健康プラザ鹿屋医療センター

《沖縄県》

社会医療法人友愛会 南部病院

医療法人翔南会翔南病院

医療法人和の会与那原中央病院

南部徳洲会病院

沖縄県立八重山病院

沖縄県立北部病院

研修関連施設 計 330 施設

なお，研修関連施設一覧は2018年 7 月 1 日現在の情報を元に作成しております.

今後名称等に変更が生ずる場合がございますのでご了承願います。また, 今後新たに指定・辞退・停止される施設もあり

ますので, 詳細や不明な点につきましては (一社) 日本循環器学会事務局へお問い合わせ下さい.

《専門医担当：TEL(03) 5501-0864 FAX (03) 5501-9855/e-mail: senmoni@ j-circ.or.jp》 


\section{8～2019年 専門医研修単位対象学術集会日程（国内）}

\section{会期}

学会名

日本循環器学会学術集会 (10単位) - 教育セッ

ション (5 単位) - 医療安全 (2 単位)

第83回日本循環器学会学術集会

第84回日本循環器学会学術集会
会場

パシフィコ横浜（神奈川県）

国立京都国際会館 他(京都府)
2020/3/13(金) - 3/15(日)

2018/ 9/22(土)

2018/10/20 (土) - 10/21(日)

2018/11/24 (土)

2018/11/24 (土)

2018/12/ 1(土)

2018/12/ 1(土)

2018/12/ 1(土)

2018/12/ 8(土)

2018/12/15 (土)

2019/2/2(土)

2019/6/22(土)

2019/4/27(土) - 4/29(月・祝)

2018/ 9/ 7 (金) - 9/9(日)

2018/ 9/14(金)－9/16(日)

2018/10/ 3(水) - 10/ 6(土)

2018/10/11 (木) - 10/13 (土)

2018/10/25 (木) - 10/27 (土)

2018/11/16 (金) - 11/17 (土)

2019/ 1/11(金) - 1/13(日)

$2019 / 2 / 11$ (月・祝) $-2 / 13$ (水)

2019/ 5/11(土) - 5/12(日) 予定

2019/6/27(木) - 6/29 (土)

2019/7/11(木) - 7/12 (金)

$2019 / 7 / 24$ (水) $-7 / 27$ (土)

2019/ 7予定
日本循環器学会地方会 (5 単位) - 教育セッショ

ン (3 単位) · 医療安全（2 単位）

第249回関東甲信越地方会

第152回東海・第137回北陸合同地方会

第120回北海道地方会

第126回近畿地方会

第167回東北地方会

第113回中国地方会

第125回九州地方会

第250回関東甲信越地方会

第113回四国地方会

第251回関東甲信越地方会

第127回近畿地方会

医学会総会（自己申告区分：5単位）

第30回日本医学会総会

循環器関連学会学術集会（自己申告区分：3 単位)

第66回日本心臓病学会学術集会

第41回日本高血圧学会総会

第71回日本胸部外科学会定期学術集会

第22回日本心不全学会学術集会

第59回日本脈管学会総会

第32回日本冠疾患学会学術集会

第21回日本成人先天性心疾患学会総会・学術 集会

第49回日本心臟血管外科学会学術総会

第55回日本循環器病予防学会学術集会 第55回日本小児循環器学会総会・学術集会 第51回日本動脈硬化学会総会・学術集会 第66回日本不整脈心電学会学術大会

第25回日本心臓リハビリテーション学術集 会
ステーションコンファレンス東京 (千代田区 名古屋国際会議場（名古屋市） 北海道大学学術交流会館 (札幌市) ナレッジキャピタルコングレコ ンベンションセンター(大阪市) 仙台国際センター（仙台市）

島根県民会館（松江市） アクロス福岡（福岡市）

ステーションコンファレンス東京(千代田区) 香川県社会福祉総合センター(高松市) ステーションコンファレンス東京(千代田区) 京都テルサ (京都市)

名古屋国際会議場, 名古屋学院大学 白鳥学舎, ウィンクあいち(名古屋市)

大阪国際会議場（大阪市） 旭川市民文化会館, 星野リゾート OM07 旭川 (旧旭川グランドホテル) (旭川市) グランドプリンスホテル新高輪 国際館パミール（港区） 京王プラザホテル（新宿区） ホテルグランヴィア広島, 広島 県医師会館（広島市） ホテル日航熊本（熊本市） 岡山コンベンションセンター(岡山市) 岡山コンベンションセンター, 岡山県 医師会館，ANA クラウンプラザホテル 岡山, 岡山シティミュージアム(岡山市) 久留米シティプラザ(久留米市)予定 札幌コンベンションセンター(札幌市) 国立京都国際会館（京都市） パシフィコ横浜 会議センター /展示場（横浜市） 大阪国際会議場（大阪市） 
2018/10/ 3 (水) - $10 / 5$ (金)

2018/11/ 3(土)-11/4(日)

2019/2/ 7 (木) - 2/ 8(金)

2019/ 3/ 1(金) - 3/ 3(日)

2019/3/28(木) - 3/31(日)

2019/4/11(木) - 4/14(日)

2019/4/18 (木) - 4/20 (土)

2019/4/19(金) - 4/21(日)

2019/4/26(金) - 4/28(日)

2019/5/10 (金) - 5/12(日)

2019/5/24(金) - 5/26(日)

2019/ 6/ 6(木)-6/ 8(土)

2019/ 6/ 7(金) - 6/ 8(土)

2019/ 6/21(金)－6/23(日)

2019/6/27 (木) - 6/28 (金)

2019/6/28(金) - 6/29(土)

2019/ 6/28(金) - 6/29(土)

2019/ 7/12(金)一 7/13(土)

2019/11/ 1(金)一-11/3(日)
関連学会学術集会（自己申告区分：1 単位）

第54回日本移植学会総会

第55回日本臨床生理学会総会

第48回日本心脈管作動物質学会年会 第46回日本集中治療医学会学術集会

第96回日本生理学会大会

第78回日本医学放射線学会総会

第119回日本外科学会定期学術集会

第122回日本小児科学会学術集会

第116回日本内科学会総会・講演会

第30回日本心エコー図学会学術集会

第92回日本超音波医学会学術集会

第61回日本老年医学会学術集会

第40回日本循環制御医学会総会・学術集会

第62回日本腎臟学会学術総会

第44回日本睡眠学会定期学術集会

第 6 回日本心血管脳卒中学会学術集会

第11回日本下肢救済・足病学会学術集会

第29回日本心臓核医学会総会・学術大会

第59回日本核医学会学術総会
ホテルオークラ東京（港区）

電気ビル 共創館 (みらいホー ル・カンファレンス）（福岡市） 富山国際会議場（富山市） 国立京都国際会館，グランドプ リンスホテル京都（京都市） 神戸国際会議場（神戸市） パシフィコ横浜（横浜市） 大阪国際会議場 他（大阪市） 石川県立音楽堂 他（金沢市） 未定

松本キッセイ文化ホール(松本市) グランドプリンスホテル新高輪 国際館パミール（港区）

仙台国際センター，東北大学川 内萩ホール, 仙台市民会館（仙 台市)

軽井沢ホテル鹿島ノ森（軽井沢 町)

名古屋国際会議場（名古屋市） 名古屋国際会議場（名古屋市） 上野精養軒（台東区）

神戸ポートピアホテル, 神戸国 際会議場（神戸市）

フォーポイントバイシェラトン 函館（函館市）

松山市コミュニティーセンター (松山市)

この表は 2018 年 7 月 6 日現在の情報を元に作成しております。今後会期, 会場などの変更が生ずることがございま す. 詳しくは直接学会事務局へお問い合わせください.

○地方会の医療安全 DVD セッションについては, 各地方会により開催が異なります。事前に各支部へ必ずご確認をお 願いいたします。

※日本成人先天性心疾患学会は 2014 年 1 月 17 日から循環器関連学会に指定されています．研修単位につきましては第 17回日本成人先天性心疾患学会学術集会参加より 3 単位付与となります.

※日本心エコー図学会は2014年 6 月 20 日から関連学会に指定されています。研修単位につきましては第26回日本心工 コー図学会学術集会参加より 1 単位付与となります.

※日本心脈管作動物質学会は2014年10月24日から関連学会に指定されています。研修単位につきましては第45回日本 心脈管作動物質学会年会参加より 1 単位付与となります.

※日本心血管脳卒中学会は2014年10月24日から関連学会に指定されています。研修単位につきましては第 2 回日本心 血管脳卒中学会学術集会参加より 1 単位付与となります.

※日本下肢救済・足病学会は2014年10月24日から関連学会に指定されています。研修単位につきましては第 7 回日本 下肢救済・足病学会学術集会参加より 1 単位付与となります.

※日本血栓止血学会は2016年12月 2 日から関連学会に指定されています。研修単位につきましては第39回日本血栓止 血学会学術集会参加より 1 単位付与となります.

※日本移植学会は2017年11月24日から関連学会に指定されています。研修単位につきましては第54回日本移植学会総 会より 1 単位付与となります. 


\section{8～2019 年 専門医研修単位対象学術集会日程 \\ (海外：2 単位)}

\section{会 期}

2018/11/10 (土) - $11 / 12$ (月)

2019/3/16(土) - 3/18(月)

$2019 / 5 / 22$ (水) $-5 / 26$ (日)

\section{学会名}

AHA Scientific Sessions 2018

ACC Annual Scientific Session \& Expo 2019

APSC Congress 2019
開催都市（開催国）

Chicago (USA)

New Orleans (USA)

Manila (Philippines)

この表は 2018 年 7 月 6 日現在の情報を元に作成しております.今後会期, 会場などの変更が生ずることがございま

す. 詳しくは直接各学会事務局へお問い合わせください. 